\title{
ANALIZA MODERNE ARHITEKTURE 1950-IH U HRVATSKOJ I EUROPI NA PRIMJERU VIŠESTAMBENIH ZGRADA DRAGE GALIĆA I LE CORBUSIERA
}

\author{
Vedran Ivanković \\ Sveučilište u Zagrebu, Arhitektonski fakultet, dr.sc., dipl.inž.arh. \\ Sanja Lončar Vicković \\ Sveučilište Josipa Jurja Strossmayera u Osijeku, Građevinski fakultet Osijek, prof.dr.sc. \\ Dina Stober \\ Sveučilište Josipa Jurja Strossmayera u Osijeku, Građevinski fakultet Osijek, dr.sc. \\ Dario Mijić \\ Sveučilište Josipa Jurja Strossmayera u Osijeku, Građevinski fakultet Osijek, bacc.građ.
}

Sažetak: Autori u članku donose usporedbenu analizu stilskih i projektantskih odrednica višestambene arhitekture hrvatskog arhitekta Drage Galića izgrađenih u drugoj polovici 1950-ih u Zagrebu i Le Corbusierove najpoznatije višestambene zgrade - Unitéa, izgrađene 1952. u Marseilleu.

Ključne riječi: Drago Galić, Le Corbusier, Unité, moderna arhitektura

\section{THE ANALYSIS OF MODERN ARCHITECTURE IN CROATIA AND EUROPE ON THE EXAMPLE OF DRAGO GALIĆ AND LE CORBUSIER CONDO-BUILDINGS}

\begin{abstract}
The authors state in this article a comparative analysis of style and design determinants of the condobuildings of Croatian architect Drago Galić built during the second half of 1950-is and Le Corbusier's most appreciated condo-building - Unité d'habitation de Marseille, built in 1952.
\end{abstract}

Key words: Drago Galić, Le Corbusier, Unité, Modern Architecture 


\section{Uvod}

Članak „Analiza moderne stambene arhitekture u Hrvatskoj i svijetu na primjeru djela Drage Galića i Le Corbusiera" bavi se problematikom komparativne analize radova dvojice poznatih arhitekata 20. stoljeća. Jedan od njih je svjetski poznat, trasirao je putove moderne arhitekture i utjecao na sva područja - od teorije do urbanizma, od dizajna do planiranja gradova i novih naselja na svim kontinentima, dok je drugi važan za hrvatsku višestambenu arhitekturu. Tema u kontekstu koje je uspoređeno arhitekotnsko oblikovanje dvaju, samo na prvi pogled jednakih višestambenih zgrada, temelji se na dvama sličnim svjetonazorima. Kako bi mogli odrediti sličnosti i razlike u njihovim ostvarenjima i misaonom konceptu te doći do određenih zaključaka, moramo se upoznati sa životima arhitekata i njihovim ranijim ostvarenjima.

Članak razrađuje i daje opis Galićevih zgrada u Ulici grada Vukovara u Zagrebu, na broju 35/35a i 43/43a, i Le Corbusierove zgrade u Marseilleu, na adresi 280 Boulevard Michelet, u kojoj su primijenjena sva načela moderne arhitekture doba koje će se sredinom 1950-ih, u osvitu kraja modernih principa u europskom arhitektonskom diskursu, tek definitivno i materijalno - u praksi dakle - oblikovati.

\section{Drago Galić}

Drago Galić rođen je u Zagrebu 9. listopada 1907. godine, a umro je 3. listopada 1992. godine. Nakon završetka srednje tehničke škole u Zagrebu (1926.) započinje stručni rad kao graditelj u Arhitektonskoj poslovnici profesora Huge Ehrlicha. Od 1929./30. radi u Arhitektonskom ateljeu arhitekata Jurja Denzlera i Mladena Kauzlarića, gdje ga upoznaje Drago Ibler koji ga poziva k sebi na Akademiju. Godine 1930. Galić upisuje Akademiju koju je završio u iznimno kratkom vremenu, diplomiravši 1933. Rad s Iblerom bio je presudan za formiranje Galićeva arhitektonskog svjetonazora, zasnovanog na racionalnim i funkcionalnim načelima s nezaobilaznom estetskom komponentom. Najbolji primjer njihove suradnje je nerealizirani projekt terasastih nizova u Novakovoj ulici u Zagrebu iz 1932./33. I drvena vila Filipčić (Sveti Duh, Zagreb) iz 1936. Galić samostalno realizira vlastitu kuću i atelier u Istarskoj 28 u Zagrebu. Godine 1935. realizira dva projekta u Dubrovniku, na Lapadu: Hotel Splendid i vilu Jakšić. Godine 1941. Izrađuje projekt plivališta s hotelom za sportaše u Preradovićevoj ulici u Zagrebu koji nije realiziran, a kojega odlikuje niz inovativnih tehničkih rješenja. Vrhunci njegova arhitektonskog stvaralaštva su dvije stambene zgrade u Ulici grada Vukovara u Zagrebu (1952.-1954.; 1955.-1959.) i zgrada na Svačićevu trgu (1951.-1954.). Nakon tih realizacija, Galić se povlači iz prakse i posvećuje pedagoškom radu na Arhitektonskom fakultetu u Zagrebu. U njegovu čast, predsjedništvo Saveza arhitekata Hrvatske (SAH) 1983. godine ustanovilo je nagradu „Drago Galić“ koja se dodjeljuje kao godišnja nagrada za najuspješnije ostvarenje na području stambene arhitekture [1].

\section{Le Corbusier}

Charles Edouard Jeanneret, poznat pod pseudonimom Le Corbusier, rodio se 6. listopada 1887. godine u La Chaux-de-Fonds u Švicarskoj, a umro je 1965. godine u Cap Martin-u u Francuskoj. Kao mladić, u Parizu radi za Auguste Perreta, a obavljao je praksu i u Njemačkoj kod Petera Behrensa. Le Corbusier i Perret smatraju da je arhitektonski izraz nužno u potpunosti promijeniti želi li odražavati tehnologiju novog doba. Nakon što napušta Perretov ured, nakon višestrukih svađa oko pristupa novoj arhitekturi gdje je mladi Jeanneret bio bitno radikalniji, odlazi u Berlin raditi u atelier slavnog arhitekta i pionira total-dizajna Petera Behrensa. U mnoge svoje građevine uveo je tehničke novine od bitne važnosti koje se i u današnje doba još uvijek smatraju prvijencima moderne arhitekture. Godine 1917. vratio se u Pariz gdje upoznaje Amédéa Oznefanta s kojim potpisuje manifest Après le cubisme. Godine 1918. s Oznefantom započinje novi pokret unutar kubizma koji nazivaju purizmom, a koji se odlikuje dominacijom čiste, funkcionalne forme i preziranjem svakog oblika dekoracije. Godine 1920. Le Corbusier i Ozenfant s pjesnikom Paulom Derméeom objavljuju časopis L'Esprit nouveau (Novi duh), posvećen svim likovnim umjetnostima, arhitekturi, građevinarstvu, glazbi, pjesništvu, industrijskom oblikovanju i „estetici 
suvremenoga života“, koji je bio čvrsta prekretnica u pariškom shvaćanju suvremene uloge umjetnosti i umjetnika. Zbirku članaka o arhitekturi, objavljivanih u časopisu Le Corbusier 1923. Godine, objavljuje u knjizi naslova Vers une architecture. Bila je to vjerojatno najutjecajnija knjiga jednog europskog arhitekta modernog doba. Ratno doba Le Corbusier posvećuje preispitivanju svojih teorijskih polazišta, a nakon rata su mu najznačajnija ostvarenja Unité à Marseille, ostala tri unitéa u Francuskoj, berlinski Unité, crkvica Notre-Dame-du-Haut u Ronchampu te projekt potpuno novoga grada, glavnoga grada indijske savezne pokrajine Punjub - Chandigarh.

\section{Višestambena zgrada u Ulici grada Vukovara 35/35a, Zagreb}

Stambena zgrada u Ulici grada Vukovara 35/35a - velikom bulevaru koji se gradio u socijalističkoj epohi zagrebačkog urbanizma [4], Galićeva je zgrada koja je odmah po izgradnji izazvala stanovitu pomutnju među arhitektima i kritičarima arhitekture, i to vjerojatno više nego ijedna druga (slika 1). lako joj nitko ne odriče kvalitetu, većina je dovodi u vezu s marseilleskim Unitéom Le Corbusiera. Poznavatelju Galićeva opusa ovog projekta bit će jasno da se ipak radi o drugačijem pristupu rješavanja osnovnih stambenih jedinica, ali su istovremeno upotrijebljeni elementi moderne arhitekture koji dovode do brojnih sličnosti, tek na prvi pogled samo oblikovnih i sličnosti pročelja. Prije svega, tu se radi o određenom problemu koncepta, jer je zgrada u Zagrebu koncepcijski potpuno jednaka Le Corbusierovu originalnom djelu.

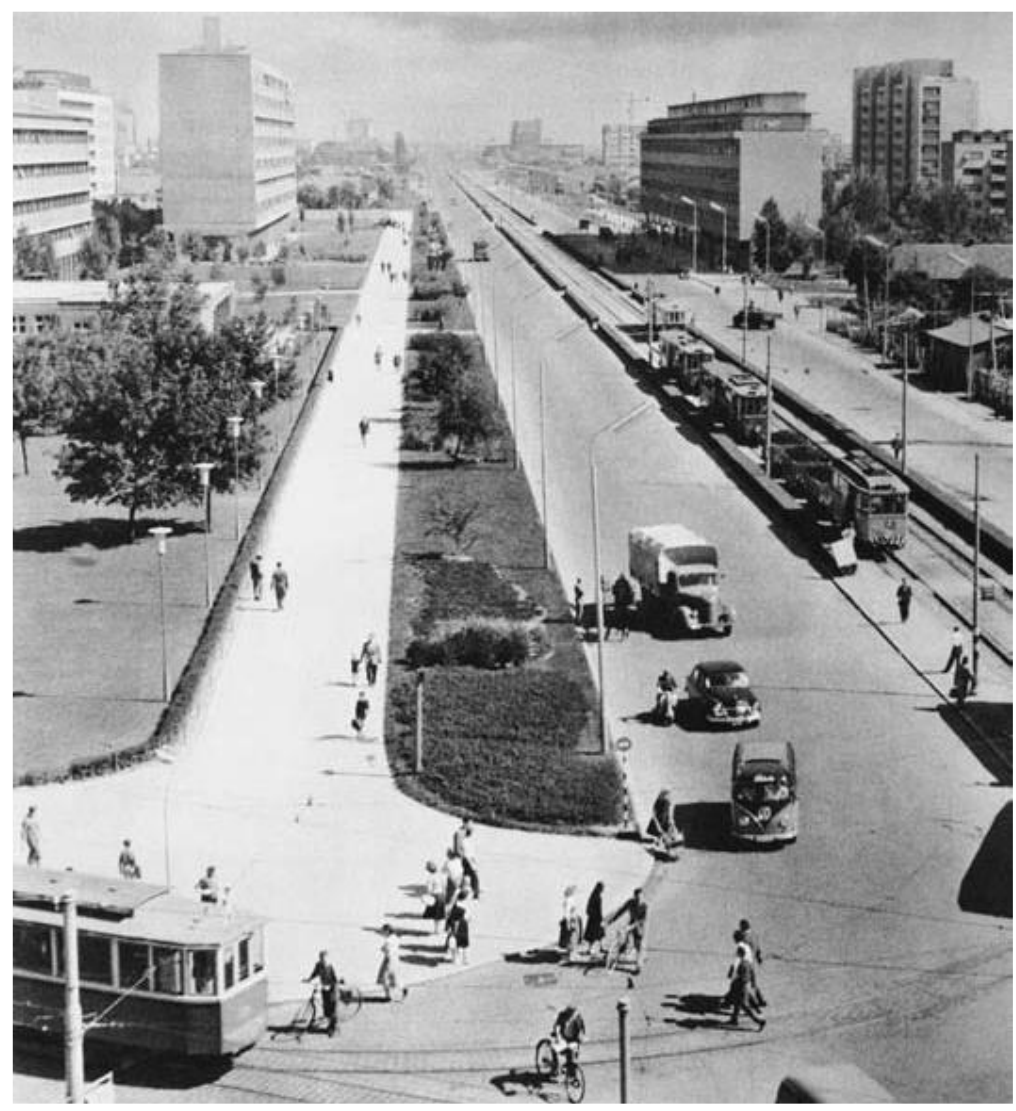

\section{Slika 1 - Ulica grada Vukovara u Zagrebu sredinom 1950-ih (tada Beogradska i Ulica proleterskih brigada). Zgrada lijevo višestambena zgrada Drage Galića na broju 35, 35a.}

Projektant zgrade bio je prof. Drago Galić, asistent ing. Josip Frankol, a statičke proračune izradio je prof. Stanko Bakrač. Gradnja je započela 1953. godine, a izvodi ju građevinsko poduzeće Tehnika. Investitor je Narodni odbor grada Zagreba. U zgradi su smještena 52 dvoetažna stana, 6 dvosobnih, 4 garsonijere, 6 atelijera i u prizemlju 12 lokala. Upotrijebljeni galerijski sustav doveden je u ovom objektu do visoke funkcionalne 
vrijednosti, ali nije iskoristio sve estetske mogućnosti takvog rješenja koje je kod Le Corbusiera nešto avangardnije koncipirano [1,2].

Galić se, nakon proučavanja potrebe što kvalitetnijeg stanovanja, odlučuje za sustav s dvoetažnim stanovima - što je bila njegova ideja u projektu iz 1942. za Preradovićevu ulicu u Zagrebu. Zgrada, predviđena kao šesterokatnica, projektirana je s dizalima, što nije bilo odmah i izvedeno jer se dizala u to vrijeme u novoj narodnoj socijalističkoj državi još nisu proizvodila, a uvoz im je bio ograničen, povremeno i zabranjivan. Izvedba centralnog grijanja također nije bila dopuštena. Smještanjem stana u dvije razine s dimenzioniranim odnosom prostorija za dnevni život i prostorija za odmor (odnos 2:1) omogućeno je uklapanje svih spavaćih prostorija na manji broj etaža budući da zauzimaju, za razliku od dnevne etaže, samo polovicu konstrukcijskog raspona zgrade (raspona stupova u prizemlju). Smanjene su i nužne horizontalne javne komunikacije, jer se one nalaze samo u onim etažama gdje su smještene prostorije za rad i boravak tijekom dana. Tako dobivamo u jednoj vrsti višekatne „aglomeracije“ ukapsuljene male obiteljske kuće. Galerije s malim predvrtovima i uvučenim ulazima tonskom raznolikošću gube karakter anonimne višestambene pozicije i odaju pomalo regionalistički, mediteranski pristup arhitekta. Sam stan predstavlja jedan od najstudioznijih tlocrta projektiranih kod nas, s funkcionalno zadovoljenim svim zahtjevima i prostorno izbalansiranim odnosima [1].

U prvoj varijanti projekta, da bi se postigla što racionalnija izgradnja, stan je projektiran s većom dubinom, a širina jedinice svedena je na minimalne dimenzije. Čisti raspon armirano betonskih rebričastih stropova je 5,6 metara, s osnim razmakom poprečnih zidova od 6,0 metara. Nakon što je investitor promijenio svoj program zamijenivši centralno grijanje pećima od glinenih kaljeva, osni raspon poprečnih zidova morao se povećati na 6,5 metara. Na zahtjev investitora, da bi sve prostorije bile što udobnije, dimenzije su još povećane na konačni raspon od 6,9 metara [1]. Ovo zorno prikazuje fotografija Milana Pavića zgrade u gradnji (slika 2).

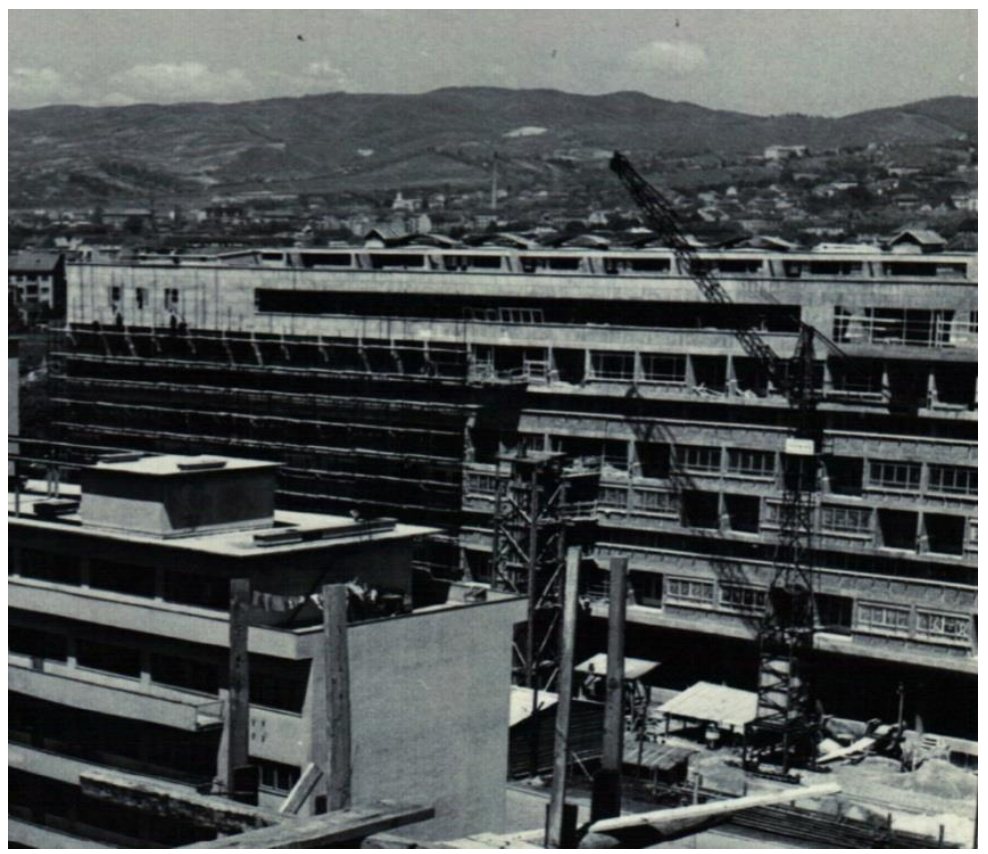

Slika 2 - Ulica grada Vukovara u Zagrebu oko 1955. (tada Beogradska i Ulica proleterskih brigada). Zgrada u izgradnji u drugom planu višestambena zgrada Drage Galića na broju 35, 35a (osobna zbirka M. Pavić, Hrvatski državni arhiv u Zagrebu; Opatička 29)

Naglašena je pozicija prostorija za dnevni boravak, dok su spavaonice vidljive na pročeljima po niskim kontinuiranim pojasevima prozora - i to samo na drugoj i petoj etaži zgrade. Na najvišoj etaži se zbog potrebe kvalitetnijeg boravka na krovnoj terasi zatvara prostor, da bi se zatim s namjerom disponirali otvori u vertikalnoj stijeni otvarajući i potrebne vizure. Tako ova višestambena zgrada dobiva svoje vanjsko obilježje iz svoje unutrašnjosti, iz sadržaja, iz potrebe stvaranja što kvalitetnijeg prostora življenja i stanovanja, a to je, čini se, jedini stalni istinski moto stvaranja Drage Galića. 
Goli zabati istočnoga i zapadnoga pročelja koji „sjede“ na dva jaka nosača istaknuta u prizemlju, iskazuju pažljivo oblikovanu strukturu oplate armiranog betona. Južno pročelje svojim jasnim horizontalizmom upućuje na Galićevu neupitnu opredijeljenost Le Corbusieru, što se vidi i iz koncepta cijele zgrade. Prizemlje je tu uvučeno, prozračno, s trgovačkim i ugostiteljskim sadržajima između jakih konstrukcijskih nosača zgrade. Time se tijelo zgrade vizualno odvaja od zemlje [3]. Galićeva zgrada je taktilno privlačna zbog načina na koji se „goli“ beton, oblikovan jednostavnim skidanjem oplate, približio mjerilu čovjeka, a početkom pedesetih to je označilo veliki kvalitativni pomak u hrvatskoj arhitekturi višestambenih zgrada [2].

\section{Višestambena zgrada u Ulici grada Vukovara 43/43a, Zagreb}

Zgrada na križanju današnje Ulice grada Vukovara i Miramarske (slika 3) projektirana je i izgrađena od sredine do kraja pedesetih godina. Tada je, dezintegracijom CIAM-a ${ }^{1}$ i sve većom kritikom Atenske povelje, slabio utjecaj Le Corbusiera i njegovih pratitelja, tzv. starije generacije modernista, među „mladim“ i „odmetnutim“ arhitektima okupljenim oko Teama $10^{2}$ te njihovim sljedbenicima diljem svijeta, kojima je po svojoj životnoj dobi pripadao i Galić. U hrvatskoj praksi arhitekti bliski Le Corbusierovim kritičarima učvrstili su bili tada svoje položaje. Galić je u nedavnom projektu, iako „mlad“, stao čvrsto na stranu „starih“. No, bez obzira na stanovitu ustrajnost u „održavanju poretka“, Galićeva je druga zgrada prepoznatljiv pomak od prve i potvrđuje arhitektov evolucijski pristup - još jedno obilježje koje ga približava Le Corbusieru [4].

$\mathrm{Na}$ ovoj drugoj zgradi opet su studiozno postavljeni betonski brise-soleili južne fasade, proračunati prema upadu zraka sunca (kao uostalom i parapeti velikih staklenih stijena dnevnoga boravka i južne spavaće sobe), perforirani poput kakve uske betonske pergole. Međutim, dok je Le Corbusierov Unite afirmacija egzemplarne plastike betona, projektiran istovremeno iznutra i izvana, u kojemu dodani prefabrikati (betonski brise-soleili, stubišta...) ne ruše konzistentnost cjeline, Galićeva struktura s neovisnim južnim pročeljem djeluje poput iznutra projektiranoga stroja koji je zatvoren s četiri tanke, vitke plohe, i to je već na prvi pogled uočljiva razlika i od prve zgrade i od Marseillea [2].

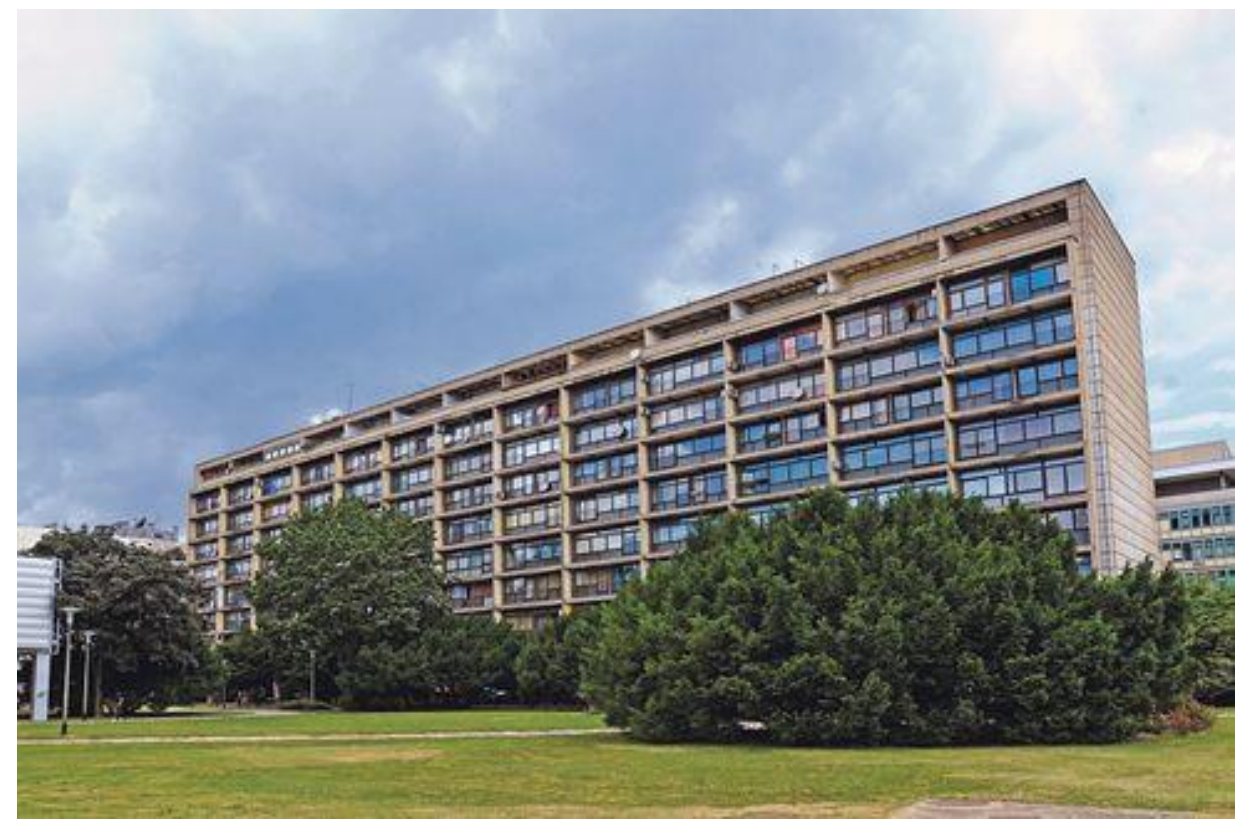

${ }^{1}$ CIAM - Congrès internationaux d'architecture modern - svjetski kongresi moderne arhitekture najznačajniji su pokret modernizma u kontekstu arhitekture i urbanizma 20. stoljeća u svijetu.

2 Team 10 ili Team X - skupina arhitekata i pozvanih sudionika okupljenih 1953. na 9. kongresu CIAM-a koji su tražili redefiniciju postavki Atenske povelje utemeljenih u okvirima CIAM-a 1933. i objavljenih u Parizu pod Le Corbusierovim autorstvom ratne 1942.

3 brise-soleil - zaštitnici od sunca, u ovom slučaju betonski koji štite terasu ili druga područja objekta od sunca 


\section{Slika 3 - Drago Galić: Višestambena zgrada u Zagrebu, Ulica grada Vukovara 43, 43a; 1959.}

Unite u Ulici grada Vukovara 43/43a eksplicitnije je postavljen na stupove od prve zgrade, čime je ostvarena prostorna povezanost prizemlja s obje strane zgrade. U njemu je 87 stanova u deset tipova. Najčešće je zastupljen dvoetažni stan u četiri tipa, koji variraju ovisno o poziciji ulaza i spavaće etaže koja, kao kod prve zgrade, može biti iznad ili ispod dnevne. Dvoetažni se stanovi ovdje razlikuju od prvih u detaljima: nemaju balkone, već kontinuirane prozore po cijeloj širini dnevnoga boravka, koji su na jednoj strani tzv. „francuski“" a u većem dijelu raspona s parapetom (isto je u južnoj spavaćoj sobi), pa je južno pročelje potpuno otvoreno, manje plastično i bliže pomalo asketskom doživljaju Le Corbusierovih „latinskih" sljedbenika, poput Oscara Nymaera [4]. Druga zgrada u Ulici grada Vukovara nema veliku zajedničku terasu sa sadržajima poput dječjeg vrtića, dječjeg bazena, teretane i trim-staze kao Unité u Marseilleu, nego samo dva izlaza iz dva stubišta na zadnjem katu na male zajedničke natkrivene prostore, iznad kojih su strojarnice liftova. Nema ni zadnje zajedničke etaže s praonicama rublja, sušionicama i velikom terasom kao kod prve zgrade [5].

\section{Višestambena zgrada Unité d'habitation, 280 Boulevard Michelet, Marseille}

Marseilleski Unité (slika 4) ima 337 stanova u 23 tipa, od hotelske sobe do stana za obitelj s 4 do 8 djece, koji ukupno ima pet spavaćih soba i standardan dnevni prostor s kuhinjom (jednak za sve dvoetažne stanove). Širina raspona stupova u prizemlju je 8,38 metara osno (16 rastera), a taj je raspon u gornjim etažama prepolovljen 4,19 metara (32 rastera). Čitava zgrada ima jedan ulaz sa središnjim stubištem i liftovima, smještenim na južnoj polovici, te dva evakuacijska stubišta i dva za vatrogasce, koji su međusobno raspoređeni na udaljenosti od 44 metra (polumjer $22 \mathrm{~m}$ ), što je dalo relativno složen tlocrt prizemlja karakterističnog po jednoličnome rasporedu stupova osnovne nosive konstrukcije. U literaturi je najčešće referiran tip stana s tri spavaće sobe u varijanti sa spavanjem gore ili dolje, ovisno ide li se iz ulaznoga prostora u spavaći dio gore ili dolje [2,6]. Dnevni prostor dvostruke visine je smješten u spavaćoj etaži, galerijski je otvoren prema gornjoj, ulaznoj etaži i od roditeljske spavaće sobe odvojen pregradnim paravanom, tako da spavaća soba dobiva dnevno svjetlo preko vertikalnih, uskih otvora u paravanu.

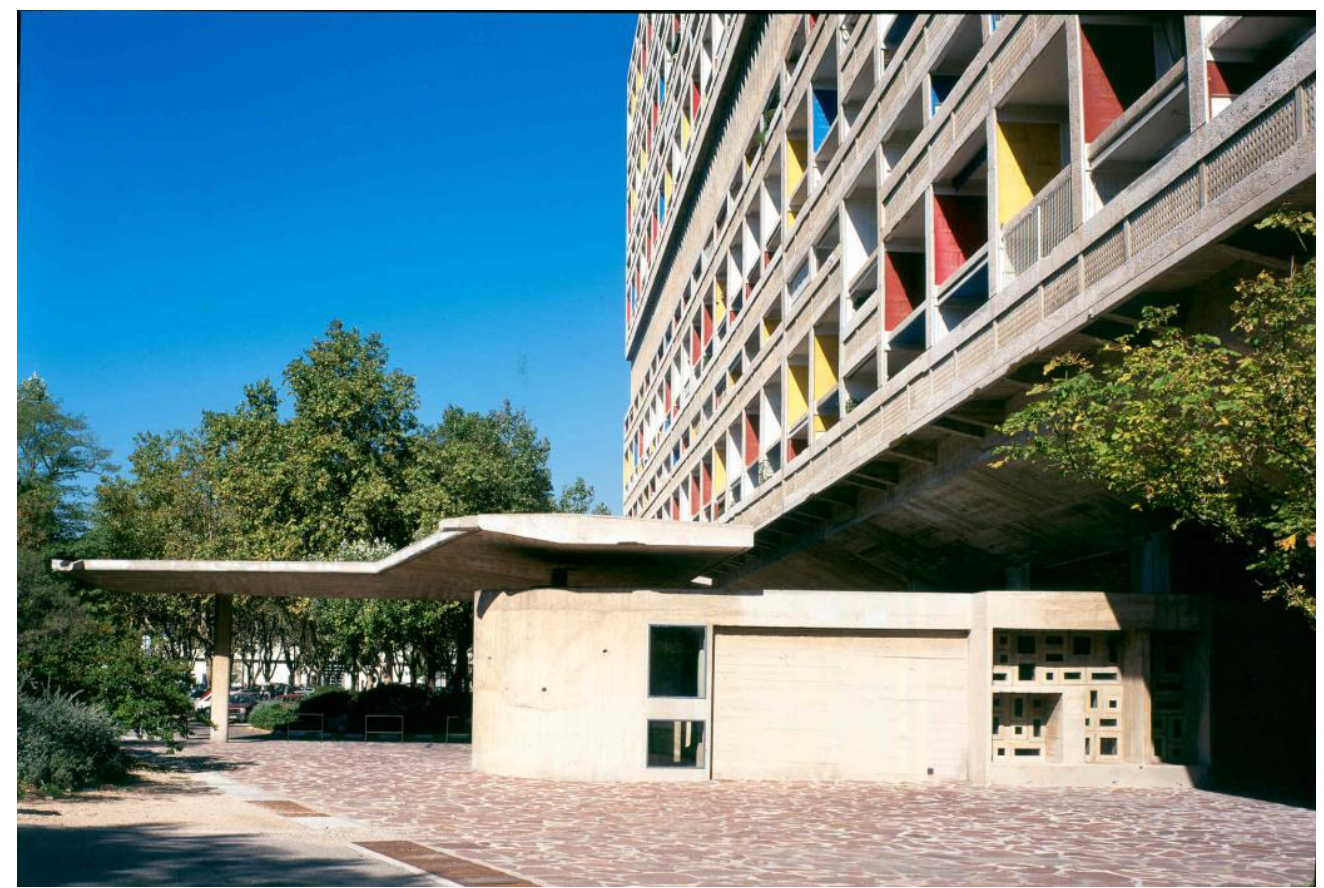

Slika 4 - Le Corbusier: Unité d'habitation de Marseille, Marseille, 289 Boulevard Michelet; 1952. 
Unité d'habitation u Marseille-u je složeno dizajnirana višestambena zgrada koja najraznovrsnije potrebe stanovnika rješava u pojedinačnim objektima, ali s naglašenim karakterom kolektiviteta. Unité ima jedinstvenu infrastrukturu, uključujući hotel, krovni vrt, bazen za malu djecu i prodajni centar. Nije slučajnost da arhitektura zgrade, kao i strukture na njezinom krovu, podsjećaju na ogromni oceanski brod kao specifičan estetski oblik koji je okupirao Le Corbusierovu imaginaciju u prethodnim radovima.

Za razliku od monotonih mreža američkih pročelja nebodera, pročelje Unitéa je djelo studioznih odnosa mjera iz Modulora, a Le Corbusier koristi četiri modificirane temeljne boje za ekspresiju dekorativnog karaktera betona. Prostor velikih vertikalnih betonskih brise-soleila ukazuje na ulicu trgovina smještenu unutar Unitéa. Izražajan izgled krova daje zgradi koja stoji na betonskim stupovima dodatni tehnološki izgled. Sirovi beton ili béton brut, bez kojeg je Le Corbusierova poslijeratna arhitektura 1950-ih praktički nezamisliva, poprima veću neovisnost kvalitativnog oblikovanja u ovoj zgradi, stojeći na jednakoj distanci s ostalim materijalima koji su do tada bili upotrebljavani u arhitekturi. Béton brut, beton nalijevan u najjednostavniji drveni kalup - oplatu da bi ispao hrapav $\mathrm{i}$ jednostavan kao prirodni kamen, namjerno dakle lomljen $\mathrm{i}$ ispucan, pun šljunkovitih površina, postaje tako od Le Corbusiera materijal verificiran i za najozbiljnije stilsko-arhitektonske pothvate u povijesti arhitekture. Dok beton ima prirodnu sivu nijansu, paneli koji razdvajaju susjedne balkone obojeni su crvenom, plavom, žutom i gotovo crnom. Na taj način svjetlucaju bočni zidovi balkona u živahnim bojama kao kroz neko betonsko, grubo pletivo. Šarene boje su upotrijebljene i u umjetno osvijettjenoj unutrašnjosti i služe rasvjettjavanju dugačkih hodnika, a lođe i sjenila štite od zvukova i sunca [7].

$\mathrm{Na}$ najvišem, sedamnaestom katu, smješteno je odmaralište za stanare - velika zajednička krovna terasa (slika 5). Jedna rampa vodi direktno na krovnu terasu gdje se nalazi, postavljena na tankim stupovima, prostorija za odmor, plitki bazen i nekoliko dječjih igrališta. Druga strana krovne terase, velike 24 x 165 metara, određena je za rekreaciju odraslih. Ovdje se nalazi dvorana za sportske aktivnosti i sportski teren, dok na sjevernom kraju velika betonska ploča služi kao zaštita od jakog sjevernog vjetra, maestrala, a istovremeno služi kao pozadina za krovnu pozornicu.

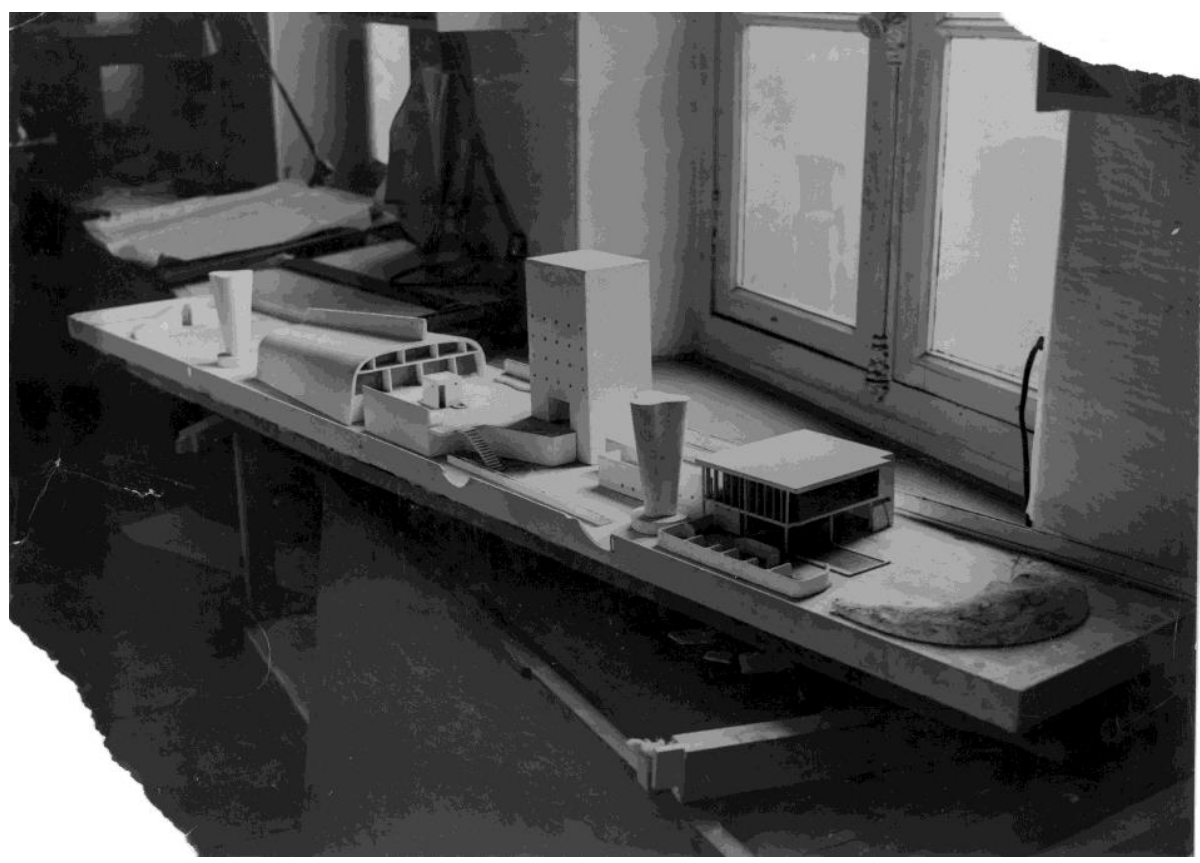

Slika 5 - Le Corbusier: maketa krovne terase marseilleskog Unitéa, početkom 1950-ih [6]

\section{Zaključak}

Le Corbusier i Drago Galić bili su dva arhitekta sličnoga svjetonazora i različitih projektantskih iskustava. Le Corbusier je u to doba bio jedan od vodećih svjetskih arhitekata koji je trasirao putove nove arhitekture. Njegov 
način razmišljanja i projektiranja postao je poticaj mnogim arhitektima 20. stoljeća, pa tako i Dragi Galiću. Oblikovanje i projektiranje prilagođava se u opusu Le Corbusiera najboljem rješenju namjene. Time on postavlja temelje modernoj arhitekturi. Galić je bio jedan u nizu arhitekata koji je pratio trendove u modernoj stambenoj arhitekturi. Ipak njegovo stvaralaštvo možemo podijeliti u dvije faze. Prvoj fazi pripadaju zgrade u Klaićevoj 44-46 i zgrada na Svačićevom trgu u Zagrebu. Međutim, kada Galić projektira zgradu u Ulici grada Vukovara 35/35a u Zagrebu, primjenjuje Le Corbusierov koncept Unitéa i tek neka dotad poznata načela funkcionalističke arhitekture iz hrvatske moderne tradicije između dva svjetska rata. Osim ove, Galić je projektirao i drugu zgradu u Ulici grada Vukovara 45/45a, koja također ima puno sličnosti s Unitéom. Najveće su projektantske razlike Galićevih i Le Corbusierovih višestambenih zgrada sustav horizontalne komunikacije (kod Le Corbusiera središnje "ulice", kod Galića sjeverne, otvorene galerije, s kojih se kao s brodskih paluba ulazi u gotovo sve zatvorene prostore zgrade) i koncepcija stanova općenito. Galić koristi raspon stupova u prizemlju kao konstrukcijsku širinu nosivih zidova u gornjim etažama, pa su dnevne etaže njegovih stanova gotovo dvostruko šire od Le Corbusierovih. Usto kod Galića nema galerijske organizacije stana koja je kod Le Corbusiera neizbježna još od prvih konceptualnih razmatranja idealne stambene gradnje i prvih takvih realizacija, poput vile La Roche 1926. Stoga Galića ne možemo smatrati „plagijatorom“ Le Corbusierova Unité, nego arhitektom koji je iz pomalo nejasnih i nepoznatih razloga napustio svoja i preuzeo Le Corbusierova uvjerenja o tome kako treba izgledati budućnost arhitekture, urbanizma, a vjerojatno i svijeta u cjelini. On je samo jedan u nizu arhitekata koji je promovirao novi način gradnje, prilagođavajući ga našim okolnostima i standardima života.

\section{Literatura}

[1] Biondić, Lj. (1996): Kritička analiza stambene arhitekture u djelu arhitekta Drage Galića - evolucija i tipologija, doktorska disertacija, Sveučilište u Zagrebu, Arhitektonski fakultet, Zagreb

[2] Ivanković, V. (2009): Le Corbusier i Drago Galić - kritički eksperimenti arhitekture višestambenih zgrada, Prostor, Volume 17, Issue 1 (37), Zagreb

[3] Maroević, I. (2003): Antologija zagrebačke arhitekture, Art studio Azinović, Zagreb

[4] Ivanković, V. (2008): Ulica grada Vukovara 1945.-1971. i moderne vizije Zagreba u 20. stoljeću - refleksije utjecaja internacionalnog stila u hrvatskoj arhitekturi i urbanizmu nakon Drugog svjetskog rata, doktorska disertacija, Sveučilište u Zagrebu, Arhitektonski fakultet, Zagreb

[5] Mijić, D. (2012): Analiza moderne stambene arhitekture u Hrvatskoj i svijetu na primjeru djela Drage Galića i Le Corbusiera, završni rad, Sveučilište Josipa Jurja Strossmayera u Osijeku, Građevinski fakultet Osijek

[6] Ivanković, V. (2012): Le Corbusierov model Unité - Simboličko značenje u obnovi Francuske nakon Drugoga svjetskog rata, Prostor, Volume 20, Issue 1 (43), Zagreb

[7] Blake, P. (1998): Majstori graditelji, biblioteka Psefizma, Zagreb

\section{Arhivski izvori}

Hrvatski državni arhiv u Zagrebu, Opatička 29, 10000 Zagreb, Hrvatska

\section{Napomena:}

Sve slike i grafički prilozi (osim slike 2 i slike 5) su dio zbirke dr.sc. Vedrana Ivankovića. 